\title{
CPEC Dynamics; Bilateral Currency Swap Agreement and Balance of Payment of Pakistan
}

\author{
Muhammad Nadeem Javaid ${ }^{a}$, Sikander Bizenjo ${ }^{b}$ \\ ${ }^{a}$ Karachi School of Business and Leadership, Bahadurabad, Karachi, Pakistan \\ Email: nadeemjavaid75@gmail.com \\ ${ }^{\mathrm{b}}$ Dawood Hercules Corporation, 9th Floor, Dawood Center, Pidc, Karachi, Pakistan \\ Email: sikanderbizenjo@gmail.com
}

\begin{tabular}{|c|c|}
\hline ARTICLE DETAILS & ABSTRACT \\
\hline $\begin{array}{l}\text { History: } \\
\text { Accepted 13December } 2021 \\
\text { Available Online December } 2021\end{array}$ & $\begin{array}{l}\text { The China Pakistan Economic Corridor (CPEC) is considered as principal } \\
\text { strategic component of China's Belt and Road Initiative (BRI). Both } \\
\text { countries have signed deals to the tune of } \$ 46 \text { billion in 2015. Now these } \\
\text { investments and loans call for repatriation of profits and interests which }\end{array}$ \\
\hline $\begin{array}{l}\text { Keywords: } \\
\text { CPEC, Bilateral Currency Swap } \\
\text { Agreements, China, Pakistan, } \\
\text { Trade, BRI, OBOR, } \\
\text { Macroeconomics }\end{array}$ & $\begin{array}{l}\text { are causing a burden on Pakistan's, already fragile, Balance of Payments } \\
\text { (BoP). This study investigates the impact of China - Pakistan bilateral } \\
\text { currency swap agreement (BSA) on Pakistan's BoP by exploring three } \\
\text { similar cases of BSA's of China with: New Zealand, Mongolia, and } \\
\text { Ukraine. Our analysis shows that bilateral trade in all the three cases } \\
\text { has felt a strong and positive outcome but China as the foremost winner. }\end{array}$ \\
\hline $\begin{array}{l}\text { JEL C } \\
F 14, F\end{array}$ & $\begin{array}{l}\text { Our recommendations suggest how Pakistan could gain the full } \\
\text { advantage of the BSA in short, medium, and long-term. }\end{array}$ \\
\hline
\end{tabular}

DOI: $10.47067 /$ reads.v7i4.417

(C) 2021 The authors. Published by SPCRD Global Publishing. This is an open access article under the Creative Commons Attribution-

NonCommercial 4.0

Corresponding author's email address: nadeemjavaid75@gmail.com

\section{Introduction}

The bilateral relation between China and Pakistan are traced back to 1951 when Pakistan, amongst the first few countries, recognized the statehood of People's Republic of China. This connection grew stronger over the years and hit the highest note when President Xi Jinping announced an unprecedented investment deal worth 46 billion dollars in 2015 under CPEC, terming Pakistan as an "iron brother" (Mustafa \& Zafar, 2017). CPEC, which is presently valued at $\$ 62 \mathrm{bn}$, are series of investments that China is undertaking in Pakistan, including a 30ookm highway connecting China's Xinjiang region to Pakistan's Gwadar port (CPEC - LTP, 2017). It is one of the six economic corridors under China's BRI which is often referred to as Maritime Silk Road of the $21^{\text {st }}$ century. The BRI initiative envisages to connect 65 countries encompassing 40 percent of world's trade output and 62 percent of population through six land corridors and numerous sea channels (Shah, 2018). The BRI reflects a paradigm shift from traditional Chinese approach of neutral trade ties to more regional and global cooperation, 


\section{Review of Economics and Development Studies, Vol. 7 (4) 2021, 561 - 576}

encompassing economic, security and political landscape (Vangeli, 2017; Shah, 2018). CPEC, in this new 'Chinese Dream' under President Xi Jinping is not only the principal strategic component of BRI but also "the flagship project" (Shah, 2018)

The deals of such an unprecedented scale would certainly require repayments in the form of repatriation of profits on investments as well as interest payments on loans. As per International Monetary Fund (IMF) estimates, these repayments would range from $\$ 3.5$ billion to $\$ 4.5$ billion per annum from the year 2023 (IMF, 2017). Keeping in view the existing anomaly of bilateral trade with China, the CPEC and other investments related obligations are likely to put enormous pressure on Pakistan's already stumbling BoP (IMF, 2017). In order to finance these repayments, Pakistan has to boost her exports among other financial inflows, as any additional pressure on BoP at this stage will aggravate the domestic economic problems. According to the State Bank of Pakistan (2018), if the growth in exports continues at the same rate as of 2017-18, the payments linked to CPEC shall not create any additional burden on Pakistan's external payment capacity. However, Pakistan's volatile nature of export performance and competitiveness during the past necessities' serious consideration regarding the sustainability of BoP. In case, Pakistan fails to generate the required level of exports or other non-debt creating financial inflows to finance its CPEC-related obligations, then would the China-Pakistan BSA will facilitate the latter in shielding its BOP from deterioration? This study aims to explore the impacts of ChinaPakistan currency agreement in depth.

This paper is structured as follows. In Section II, we explore the literature on bilateral currency swaps. In Section III, we outlined the mutual trade between Pakistan and China, with reference to China Pakistan Free Trade agreement (FTA) and CPEC. Section IV presents the basis of analysis and investigates the three case studies on which Pakistan's case can be analyzed. And Section V presents the conclusion and policy recommendations.

\section{Understanding Bilateral Currency Swap Agreements}

According to the IMF, BSA is defined as, “... an agreement between two central banks to exchange a cash flow in one currency against a cash flow in another currency according to predetermined terms and conditions" (IMF, 2017, p. 4). To illustrate further, a BSA is signed between People's Bank of China and another Central Bank, then the counterparty Central Bank is able to sell it's currency to China for Renminbi (RMB) - also known as the Yuan - at a pre-agreed exchange rate date in the future (Zhitao, Wenjie, \& Cheung, 2016). Further, the RMB is then lend to the local banking sector to do trading with China. In other words, BSA propels liquidity to conduct RMB-dominated trade overseas (Bank of Korea, 2012).

BSAs came into light in the 1970s and since then have been expanded substantially. These agreements have risen from $\$ 3.8 \mathrm{bn}$ in 1995 to $\$ 31.5 \mathrm{bn}$ in just over a decade (Munro \& Wooldridge, 2010). The need for these agreements have become more imminent after the fall of Wall Street and in the aftermath of global financial crisis in the 2008-09 (Park, 2016). It was against this backdrop that many currencies were set to replace the US dollar in the international monetary market. Euro for one was the top contenders; the global foreign exchange reserves of Euro rose from 17.9 percent in 1999 to 28 percent in 2009 (Park, 2016). Similar to Europe, Beijing too was quick enough to seize this opportunity of uncertainty in the global financial markets. China first took the center-stage in the global economy in 2009 when they became world's largest exporter and second largest importer. And by 2014, they were the largest trading economy in the world (Park, 2016). These ambitions were further enhanced as China aimed to have RMB as the dominating trading currency of the world. These agreements are used by China to aid a partner country in need outside the Bretton wood institutes (McDowell, 2019). Since 2009, China has sealed around 32 BSAs (Spivak, 2017). Many new partner countries have signed currency contract with China, including Pakistan. Although, Pakistan holds a special significance due to its trade relationship with China, vis-à-vis CPEC. Researchers have extensively explored the implications of BSAs; however, the literature on BSA in relation to Pakistan is extremely weak and this paper aims to fill this gap. 


\section{Pakistan's BoP and its trade ties with China}

Pakistan had witnessed a reasonably good trade balance during the early years of her inception. The current account balance of Pakistan has seldom been stable as evident from the Figure 1. To illustrate with the help of graph (Figure 1), the data extracted from World Bank approximate that the trade balance was stable during the 1980s and 9os, but took a sharp decline around 1995 and 1996. Despite the fact that workers' remittances have surged during this period, the overall trade balance had deteriorated. For instance, in 1994 and 1996, the deficit in current account on an average increased from $\$ 3.1$ to $\$ 3.6$ billion respectively. On the contrary, the years leading up from 2001 witnessed a sweeping upsurge; trade deficit was low and the current account was in surplus for the first time in country's history (SBP, 2001). The predominant factor behind this surplus of \$1.3 million in 2001 and \$3.1 million in 2003 were due the events unfolding post 9/11 attack in the US; the coalition support fund in the war against terror and easing of tariffs had contributed in ameliorating Pakistan's BoP (SBP, 2001). This upsurge lasted for 7 years before current account plummet to \$15bn during 2008-09, owing to the global financial crisis.

\section{Figure 1: PAKISTAN'S BALANCE OF PAYMENT TIMELINE}

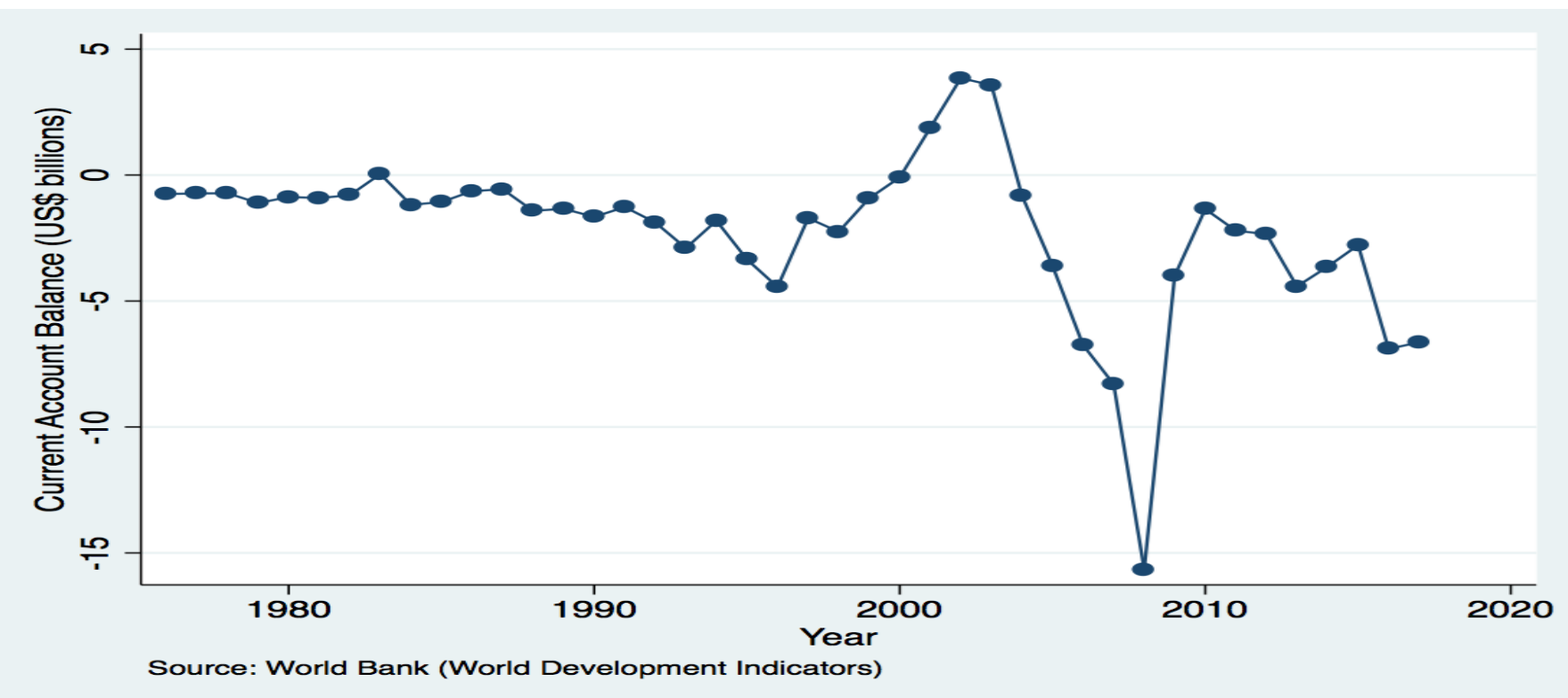

It is pertinent to note that Pakistan has traditionally maintained an import substitution regime instead of an export orientation (SBP, 2001). Notably, Pakistan had the same approach with its regional trade partners as well, including China. The present bilateral trade between Pakistan and China is highly in favor of the latter as depicted in Figure 2. Nevertheless, many new developments in the country, including CPEC and BSA with China are silver-linings that this anomaly in bilateral trade may change to make this partnership more balanced.

China and Pakistan have enjoyed an "all-weather" friendship based on their mutual interest in trade and geo-politics (Mustafa \& Zafar, 2017). The friendship was given a physical shape in 1982 with the construction of Karakoram Highway (KKH) - often known as the eighth wonder of the world - that connects Chinese city of Kashgar to Pakistan's Gwadar. Albeit, the relation of trade goes well before KKH to 1963 when both of the countries signed their first bilateral agreement (Kumar, 2006). This was followed by the establishment of ChinaPakistan Joint Committee to facilitate fostering of trade and technology in both countries. It uplifted the trade and the new dawn of Memorandum of Understandings (MoUs) begun; six MoUs were signed in May 2001, seven in 2004 and twenty-one in 2005 (Kamal \& Malik, 2017). These MoUs were to expand the cooperation in trade, defense, energy, infrastructure, social sector, among other areas. The mutual trade received even a bigger forward push with the agreement on Early Harvest Program in January 2006 which are often labelled as the foundation stone of the China Pakistan Free Trade Agreement (CPFTA) (Kamal \& Malik, 2017) 


\section{Trade Between China and Pakistan and its implications on Pakistan's BoP}

Pakistan and China signed their free trade agreement in 2006, which has significantly boosted the mutual trade between the two neighboring countries. The volume of bilateral trade in 2015 was $\$ 13.77 \mathrm{bn}$, approximately \$1obn more than what it was in the 2002 (Ministry of Finance, 2018). Moreover, as per the CPEC's Long Term Plan (LTP), based on the Tariff Reduction Modality, both of the parties eliminated almost 36 percent of total tariff lines in the first phase, which concluded in 2012 (CPEC - LTP, 2017). The negotiations for the second phase had begun in 2013 and are still going on till date. Since the FTA, the trade between two countries had considerably improved; still, highly skewed in favor of China.

To give an illustration, the Figures 9 to 11 in the appendix show the composition of trade between both countries for two different periods; 2006 as the baseline year when the FTA was signed and a decade later in 2016. There are some changes in the exports but the overall composition of the imports of both countries remain almost the same. It is pertinent to note that both of the countries have benefited from signing CPFTA, but the accumulated trade is highly skewed towards China. For instance, the exports to China from 2006 to 2016 have increased by 214 percent, as oppose to imports from China, which have augmented by 369 percent. In view of research by Pakistan Business Council, the utilization of tariff reduction under CPFTA for Pakistan remains at mere 4 percent, against China's 60 percent (PBC, 2018). The bilateral trade overtime is further boosted with the advent of CPEC under the BRI initiative. The tenancy of trade in favor of China has strained the current account balance of Pakistan and consequently asserting pressure on the BoP of the former.

The trend of trade in Figure 2 shows that Pakistan's imports have witnessed a sharp surge from 2013 onwards. Conversely, the exports have only managed to increase until 2013, before proceeding on a decline trend. This discrepancy in country's trade pertinent to China is due to both demand and supply side factors. For instance, according to National Tariff Commission (2015), high cost of doing business in Pakistan is one of the dominant causes of decline in exports. In addition, the inefficiency and red-tapism is also adding up to the cost of doing business and making Pakistan's exports uncompetitive in the international market. Similarly, energy crisis and high energy tariff are adding to the cost. Furthermore, exports stagnation is also due to non-innovative export policies and paucity of identifying new export base in China (PBC, 2018). Additionally, China surpasses Pakistan in most of the trade sectors. For instance, Pakistan's primary exports is textiles but China itself is a giant supplier of textiles and enjoys greater comparative advantage, thus causing a skewed trade policy in favor of China (Kamal \& Malik, 2017). Other non-quantifiable reasons behind low exports in Pakistan are: meagerness of market diversification, political and social instability, abysmal market access and trade facilitation, less educated and skilled force among others (NTC, 2015).. In the recent years, overvalued Pakistani rupee has further constrained the export flow from the country. Another shift comes from the demand-side owing to China's preferential change from low-tech products like textiles to more high-tech products (Liang, 2008). Pakistan's exports to China are mainly low-valued, and such industries in China itself are relocating to other countries as they are loosing their advantage in China (PBC, 2018). Notably, the present dip is also due to the slowing down of Chinese economy from 2013 onwards. On the other hand, the imports from China have been rising since singing the CPFTA in 2006. The largest increase have come from 2013 onwards which is largely explained by the imports of expensive machinery and equipment under the backdrop of CPEC (IMF, 2018). And finally, a sizeable number of power projects under the umbrella of CPEC are supported by imported coal from China; thus, further boosting the import bill (CPEC - LTP, 2017; PBC, 2018). 


\section{Figure 2: Pakistan China Trade (Post CPFTA)}

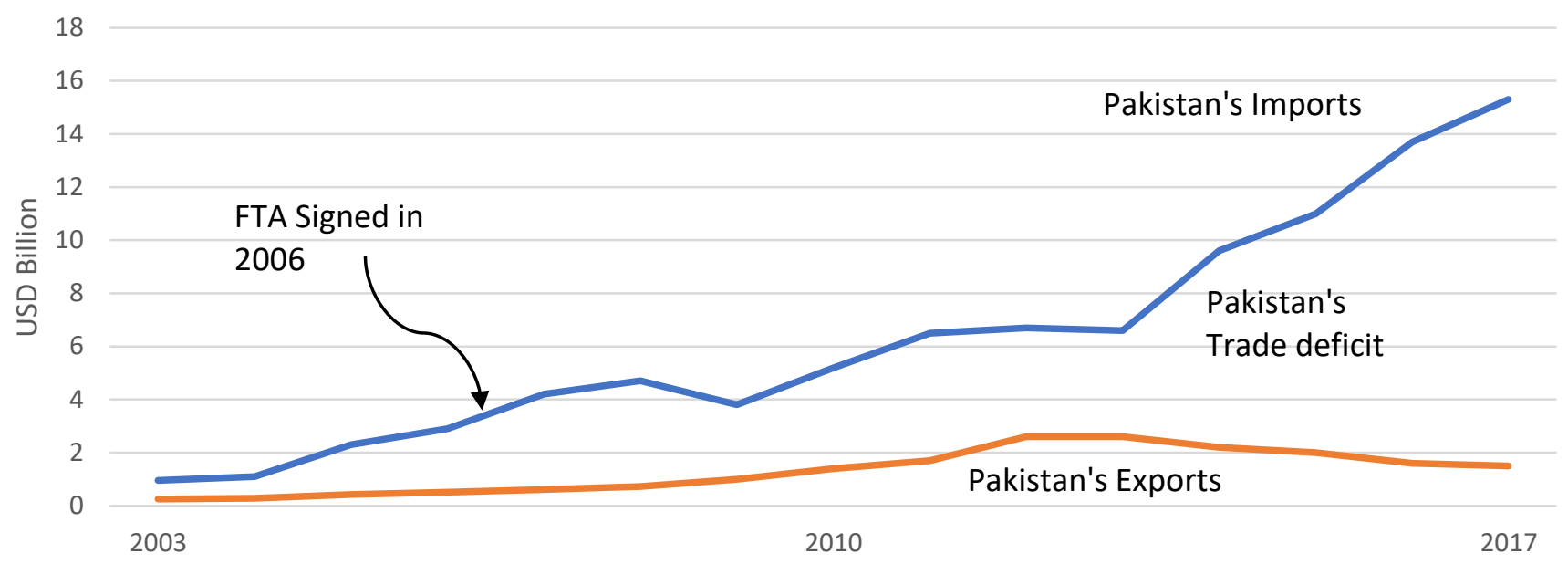

Source: Date collected from OEC and Pakistan Bureau of Statistics

\section{CPEC as the principal strategic component of BRI}

CPEC is one of the six corridor under China's One-Belt One-Road (OBOR) initiative, also known as BRI. It is an attempt to expand Chinese economy through creating a mutually beneficial network of economies. China has heavily invested in the financial and economic sectors in various countries in order to shape global economic governance (Giuseppe Gabusi). This mega investment is being termed as the magnum opus of Chinese Premier Xi Jinping's government (Swaine, 2015). These ambitious plans under BRI are set to connect mainland China with many of its neighbors across continents, spanning over 65 countries (Irshad et al 2015). According to Vangeli (2017), BRI reflects the will of Chinese government to be a world player through aligning their economic and policymaking frameworks with global governance issues. BRI is envisaged to promote China's ambitions of converting strategic partnerships into economic ones (Huang, 2016). Within BRI, CPEC is the most expensive of its projects to-date, as it has already surpassed a whooping $\$ 60 \mathrm{obn}$ investment (Small, 2017). In the words of Chinese Foreign Minister Wang Yi, "If 'One Belt, One Road' is like a symphony involving and benefiting every country, then construction of the China-Pakistan Economic Corridor is the sweet melody of the symphony's first movement." (Small, 2017, p. 81). CPEC is seen as a gateway for Pakistan to steer its economy on a sustainable upward movement. The effects of CPEC on Pakistani economy are already visible; the mutual trade between China and Pakistan have the growth rate of 18.8 percent on average and the former has surfaced as the largest source of foreign capital for latter (CPEC - LTP, 2017). However, the mutual trade between the two countries is highly tilted in favor of China.

Investments under CPEC will soon call for repatriation of profits and interest payments back to China. According to an estimate by the IMF, from the year 2024-25 onwards, Pakistan will have to pay approximately \$3.5 to \$4.5billion per annum1 (IMF, 2017), coupled with already high import bill and stagnant exports. Therefore, some alternative measures would be required to settle this growing pressure on Pakistan's BoP. BSA could facilitate in the short-term meanwhile some robust long-term interventions would be needed for smooth functioning of the Pakistan economy.

\section{Analysis}

The CPEC investments have touched a whooping $\$ 62 \mathrm{bn}$ and is spread across the range of sectors in Pakistan. As the Early Harvest Projects under CPEC are about to be realized, Pakistan has to design a framework of paying back the obligations in order to avoid a BoP crisis, which may threaten the stability of its currency or ability to pay for imports. A report by the State Bank of Pakistan extrapolates that Chinese firms, who have invested in CPEC are entitled a US $\$ 17$ percent return on equity. The situation is further worsened by a downward 
trend of exports as shown in Figure 3. Exports have declined from $\$ 25$ billion in FY2013 to \$20 billion in FY2016, a substantial 20 percent drop in just 4 years before picking up in 2017. Reductions in energy shortfall in the country is the key factor contributing to the growth in the exports, as the largest portion of CPEC investments are drawn towards improving the energy sector (CPEC - LTP, 2017).

\section{Figure 2: Trend of Exports in Pakistan}

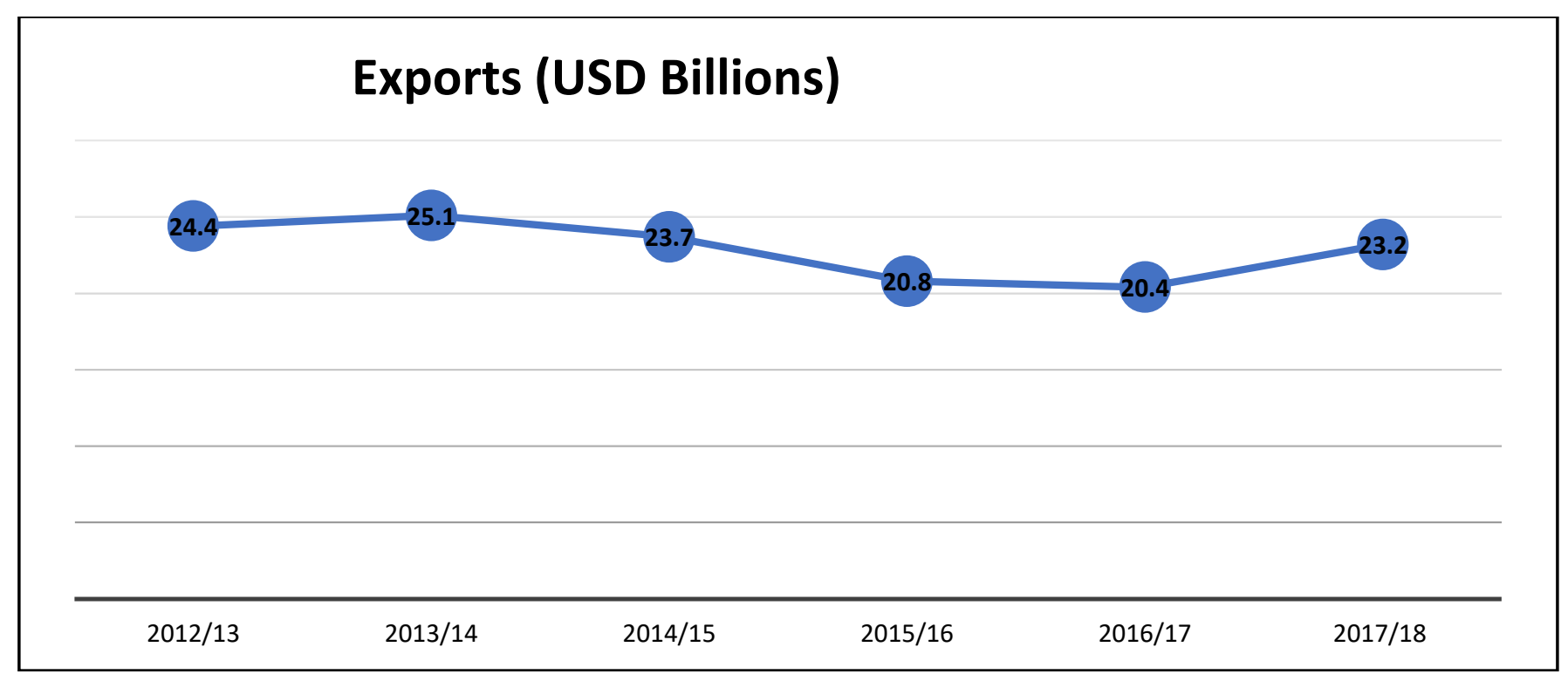

Source: Date collected from Pakistan Bureau of Statistics

If the export sector had not encountered an energy crisis, the projections in Table 1 show that a 10 percent growth in 2017-18 would have increased the exports to \$39 billion. Keeping in a more modest estimate of a mere 5 percent increase, the exports would have still touched $\$ 30$ billion by 2017-18. As the situation of energy normalizes in the country, exports have presented a positive growth of approximately 14 percent in 2017 and are projected to keep growing. Consequently, the imports have surged drastically, from $\$ 53$ billion in FY2016 to $\$ 60$ billion in FY2017 2. This 13 percent increase is mainly due to the imports of expensive and heavy machinery to facilitate the CPEC projects. However, through analyzing the data from PBS (2018), a more holistic view of imports displays that on average, the imports have only increased to 4.6 percent per annum in the last decade from 2007 to 2017. Given the existing growth rate in exports, the imports would less likely to build additional pressure on the BoP. The recommendations at the end of the paper would further provide blueprints on where more to cut down on the imports and where to enhance the export bill. 
Review of Economics and Development Studies, Vol. 7 (4) 2021, 561 - 576

TABLE 1: Trends and Projections of Pakistan's Export Revenue

(USD Billions)

\begin{tabular}{|l|l|l|l|l|}
\hline \multicolumn{2}{|l|}{ 2012-2013 to 2017-18 } & Actual growth & \multicolumn{4}{l|}{ If Exports had grown at: } \\
\hline Years & & $5 \%$ & $10 \%$ & $15 \%$ \\
\hline & 24.4 & - & - & - \\
\hline $2012 / 13$ & 25.1 & 24.4 & 26.8 & 28.1 \\
\hline $2013 / 14$ & 23.7 & 25.6 & 29.5 & 32.3 \\
\hline $2014 / 15$ & 20.8 & 26.9 & 32.5 & 37.1 \\
\hline $2015 / 16$ & 20.4 & 28.2 & 35.7 & 42.7 \\
\hline $2016 / 17$ & 23.2 & 29.7 & 39.3 & 49.1 \\
\hline $2017 / 18$ & & & & \\
\hline
\end{tabular}

TABLE 2: Projections of Pakistan's Export Revenue (USD Billions)

\begin{tabular}{|l|l|l|l|}
\hline 2018-19 to 2023-24 & \multicolumn{5}{l|}{ If Exports grow at: } \\
\hline Years & $5 \%$ & $\mathbf{1 0} \%$ & $\mathbf{1 5 \%}$ \\
\hline $2018 / 19$ & 24.4 & 25.5 & 26.7 \\
\hline $2019 / 20$ & 25.6 & 28.1 & 30.7 \\
\hline $2020 / 21$ & 26.9 & 30.9 & 35.3 \\
\hline $2021 / 22$ & 28.2 & 34.0 & 40.6 \\
$2022 / 23$ & 29.6 & 37.4 & 46.7 \\
$2023 / 24$ & 31.1 & 41.1 & 53.7 \\
\hline
\end{tabular}

Source: Data collected from Pakistan Bureau of Statistics

If Pakistan manages to increase her exports as per the projections in Table 2, a 10 percent increase will bring the export revenue to $\$ 41$ billion by 2023. An estimate by State Bank approximates that if the export bill is risen to $\$ 40$ billion by the year 2023, the payment stream of CPEC projects would not cause any stress on BoP (Hussain, 2018). However, should the circumstances change and Pakistan could not finance the CPEC payments through her export bill, will the BSA complement it? To answer this question, this paper has employed an approach of comparing the BSAs with matching characteristics to Pakistan's and then generalizing the results to predict Pakistan's future gains or losses.

\section{Methodology and Case Studies}

The study has applied a comparability model which will first isolate the agreements that were similar in value with that of China and Pakistan's agreement. The BSA between China and Pakistan is currently valued at $\mathrm{CNY}$ 2obn or $\$ 3.3 \mathrm{bn}$, so only those agreements will be selected if they are close to this range. Furthermore, only those agreements will be considered which were signed prior to 2015 to avoid an estimation bias of immaturity of BSA in the analysis. This paper will evaluate the overall trade, the composition of trade and the trends of trade under the backdrop of BSA to propose relevant policy implications for Pakistan to benefit from this agreement.

The overall analysis of these BSAs which involve China and one other party indicate that only 3 agreements are meeting the criterion. First, it was the BSA with New Zealand, which is worth at \$3.9bn, signed in April 2011. Second, the BSA between China and Mongolia, which was signed in May 2011 with the worth of \$2.36bn. And third, the BSA with Ukraine, signed in June 2012 also valued at \$2.36bn. Apart from the aforementioned BSAs, other BSAs with China are not meeting the conditions of this methodology. 
Review of Economics and Development Studies, Vol. 7 (4) 2021, 561 - 576

According to Yelery (2016), the primary rationale behind China's BSAs with these specific countries are mainly driven by trade. Numerous studies have proffered that the priority is given to those countries with whom China has been involved in colossal trade (Yelery, 2016). Furthermore, China has been cautiously selecting the countries that hold crucial geographical positions in their respective regions, have a strong political alignment towards China and are likely to support the latter in ending what they term as the notorious "dollar trap" through internationalization of RMB (Yelery, 2016). The countries that are vulnerable to dollar volatility and could benefit from such BSAs are partnering with China.

\section{New Zeeland and China}

The mutual trade volume between New Zealand and China has been sky-rocketing. Within two years of signing the BSA, China took over Australia as New Zealand's top trading partner. The composition shows that the trade is not skewed towards any party but is almost comparable for both. The exports from New Zealand to China were valued at $\$ 8.8 \mathrm{bn}$, whereas, the imports from China were at $\$ 8 \mathrm{bn}$ in 2017 (Stats NZ, 2018). The top 5 primary exports to China are: concentrated milk, rough woods, acyclic alcohols, sheep and goat meat and frozen bovine meat, and the major imports are: computers, broadcasting equipment, telephones, furniture and seats (OEC, 2018). The target which was set by both countries to reach $\$ 2$ obn bilateral trade was just revised to \$3obn by the year 2030. The success of this agreement is evident from the fact the bilateral trade between these two countries has increased by three fold in the last decade. Figure 4 that the overall trend for both imports and exports is growing. In 2017, both imports and exports have witnessed their all time highest.

Figure 3: NZ's Trade in Good and Services with China

(USD Billion)

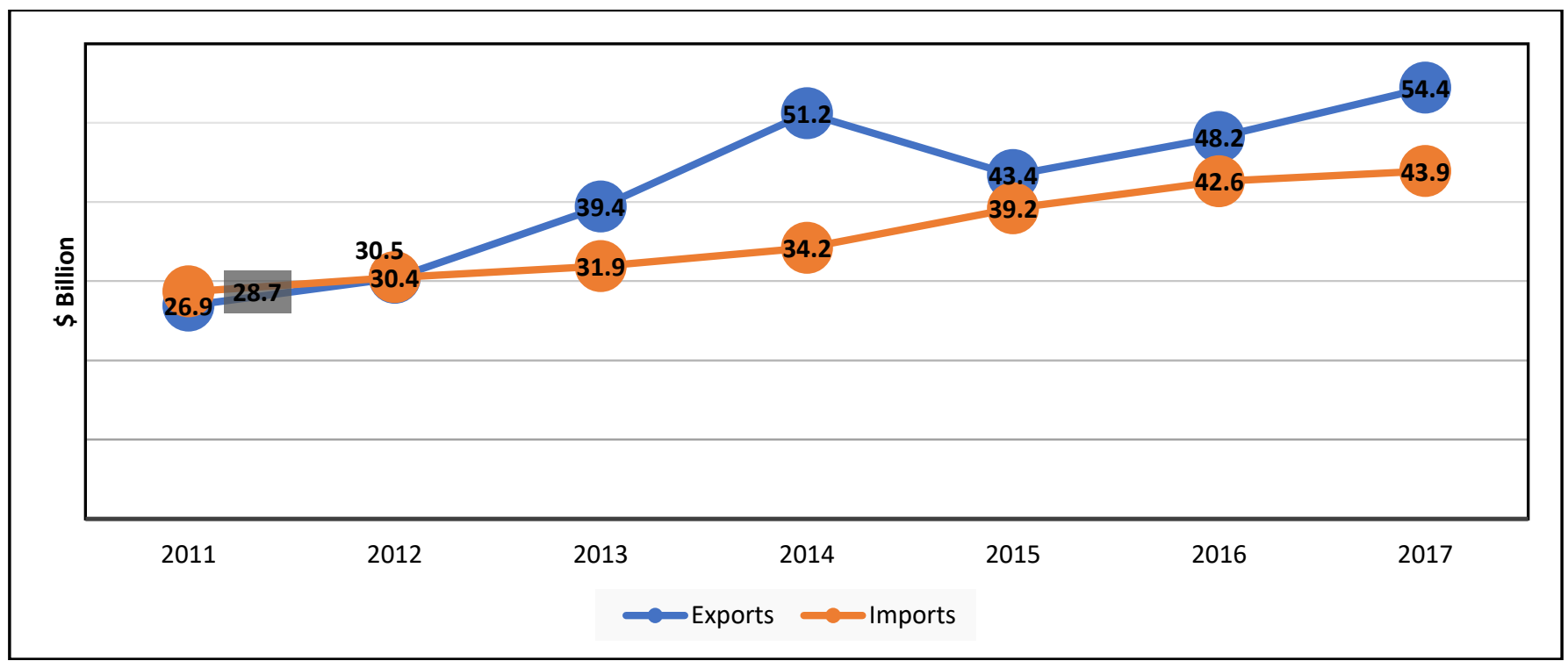

Source: Date collected from Stats NZ

\section{Mongolia and China}

Mongolia is a landlocked country and disadvantaged in terms of trade for not having a seaport. However, their trade dynamics completely changed when they signed a BSA with China. The agreement between People's Bank of China and Bank of Mongolia was signed in 2012 for the total worth of CNY 5 bn but it was later increased to CNY 1obn. The analysis of the trade between the two countries shows that China is the largest trading partner of Mongolia in terms of both exports and imports. The composition of their bilateral trade shows that 80 percent of Mongolia's export market is in China, while only 37 percent of overall imports are coming from China. It is pertinent to note that Mongolia's imports are more diversified than its exports. The the primary exporting commodities to China are: copper ore, coal briquettes, crude petroleum, iron ore and animal hair, whereas, the major imports from China are: electricity, telephones, stone processing machines, other iron products and iron structures (OEC, 2018). The recent statistics in Mongolia's foreign trade review shows that in 2017, the trade turnover with China has increased to almost 50 percent (Bank of Mongolia, 2017). In the words of former Mongolia Prime Minister, Sukhbaatar Batbold, trade with China will provide the country with “... economic 
opportunities that could to a certain extent offset the disadvantages associated with the lack of Mongolia's access to the sea." (Anzai, 2018). Figure 5 shows that Mongolian exports in 2015 have been the highest, whereas they have remained stagnant in other periods at approximately $\$ 3 \mathrm{bn}$ to $\$ 4 \mathrm{bn}$ on average per year. The imports from China on the other hand show a declining trend. It is worth noting here that Mongolian economy was battling a severe economic crisis before IMF came to rescue in 2017 and approved a three-year bailout program. Despite the fact that Mongolian economy was in shambles, the bilateral partnership has touched unprecedented heights as China is now the largest trading partner and investor in Mongolia. The share of exports to other trading partners is almost stagnant to what they were in 1995 (Vorshilov \& Ulzii-Ochir, 2016).

\section{Figure 4: Mongolia's Trade in Goods and Services with China (USD Billion)}

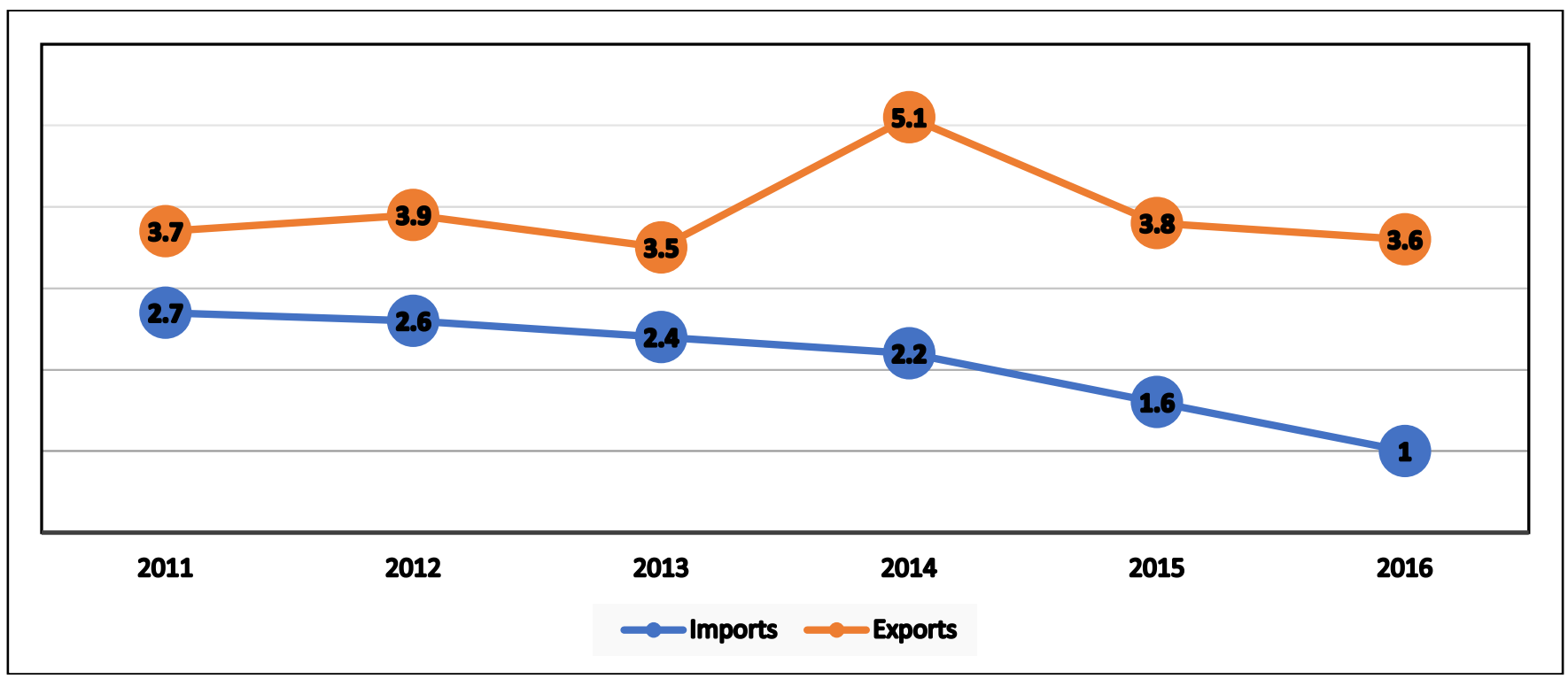

Source: Data collected from World Bank

\section{Ukraine and China}

Ukraine is the third country that has a relatively comparable sized BSA with that of China-Pakistan's. The trend of bilateral trade between Ukraine and China seem to be uncertain as depicted in Figure 6. Imports have taken a hit in 2015 and 2016, before slightly picking up in 2017. Similarly, exports were stagnant in 2016 and fell in 2017. The composition of the trade shows that the major exporting products to China are: iron ore, seed oil, corn, rough wood and soybean. And the primary imports from China are: telephones, iron, rubber footwear, broadcasting equipment and pesticides (OEC, 2018). It is pertinent to note that Ukraine was hit by a politicalcum-security crisis in 2013 when the tensions between Ukraine and neighboring Russia soared in November 2013. The situation slightly eased down in 2015 but reports surmise that Russian intervention in Ukraine continues to date, thus the uncertainty in their trade dynamics (OSCE, 2016). 
Figure 6: Ukraine's Trade in Good and Services with China (USD Billion)

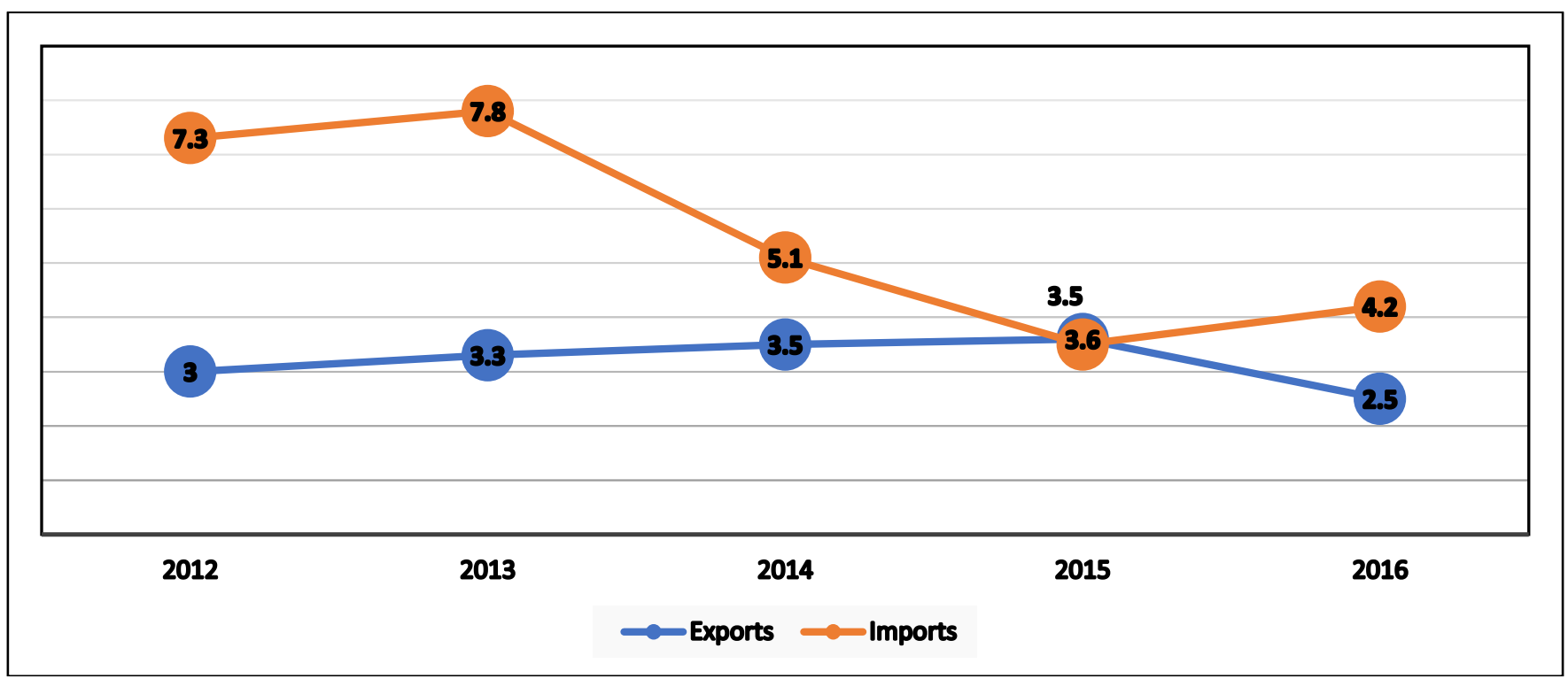

Source: Data collected from World Bank

\section{China-Pakistan BSA and Trade - lessons from Case Studies}

The analysis of three BSAs that are fulfilling the criteria of the employed methodology shows that bilateral trade in all the three cases have reckoned a strong and positive outcome. China has become the largest trading partner of New Zealand and Mongolia, and one of the significant trading partner of Ukraine. Therefore, based on the above case studies the ballooning of overall trade under the backdrop of BSA is highly probable. It is worth mentioning that China has only signed a FTA with New Zealand, their trade with Mongolia and Ukraine is not boosted by any such agreement, yet. Secondly, as far as the composition of the trade is concerned, the exports of New Zealand and Mongolia to China are greater than what they are importing. In case of Ukraine, the composition is reversed and trade is more skewed towards China. Albeit, as mentioned earlier, the case of Ukraine cannot be validated under the present circumstances when the country is battling security challenges. Finally, the trend analysis indicates that imports and exports for New Zealand - apart from few fluctuations have an increasing trend. In case of Mongolia, exports show a slight increase at first but then they remained stagnant, whereas the imports have a declining trend since the signing of the BSA. The trend in Ukraine is rather inconsistent due to prevailing conflict.

\section{TABLE 3: Trade with China Post-BSA}

\begin{tabular}{|c|c|c|c|}
\hline \multirow[b]{2}{*}{ Overall trade } & New Zealand & Mongolia & Ukraine \\
\hline & $\begin{array}{l}\text { China emerged as } \\
\text { the largest trade } \\
\text { partner }\end{array}$ & $\begin{array}{l}\text { China emerged as the } \\
\text { largest trade partner }\end{array}$ & Uncertain \\
\hline Composition of trade & $\begin{array}{l}\text { Almost comparable: } \\
\text { not skewed in favor } \\
\text { of either party }\end{array}$ & $\begin{array}{l}\text { Skewed favor of } \\
\text { Mongolia: } \\
\text { quantity is larger than } \\
\text { imports }\end{array}$ & Uncertain \\
\hline Trends of trade & $\begin{array}{l}\text { Upward trend for } \\
\text { both exports and } \\
\text { imports }\end{array}$ & $\begin{array}{l}\text { Stagnant exports and } \\
\text { downward imports }\end{array}$ & $\begin{array}{l}\text { Downward trend for } \\
\text { exports and slightly } \\
\text { upward for imports }\end{array}$ \\
\hline
\end{tabular}

It is worth noting that the central focus for Pakistan at this stage is to boost her exports to China in order to shrink its trade deficit. The indications here are establishing that with the BSA, Pakistan's exports to China are likely to grow if managed properly. 


\section{Conclusion and Policy Recommendations}

Based on these findings, this paper has extrapolated short, medium and long-term policy recommendations for the Pakistan's relevent government bodies to adopt in order to gain the maximum benefits of the BSA with China, and use it as a means to improve its exports to China. There is a growing pessimism in Pakistan about its ability to repay CPEC-related obligations and a possible BoP crisis in making. At this conjunction, Pakistan has a good chance to seize the opportunity and utilize the BSA in its favor and ameliorate its trade dynamics with China.

The findings of the case studies presume a positive indication for Pakistan. This BSA can certainly turn out to be a golden opportunity for the country. And in short and medium term at least, BSA will aide in ameliorating the bilateral trade between both trading partners.

Short and Medium Term Policy Recommendations

I. BSA being short term in nature, Pakistan has to maximize its benefits in the next three years by boosting exports, simultaneously identifying new products to export to China;

II. Negotiate better terms with China regarding Free Trade Agreement and further reduce tariff lines, specially on the products that Pakistan has comparative advantage. For instance, the tariff rate for Pakistan on semi-milled or wholly milled rice stands at 65 , whereas the tariff rate from China's top importer Vietnam is at 35;

III. Utilizing BSA and CPFTA, Pakistan should identify new product markets in China. For instance, being an agrarian economy, Pakistan should tweak its agriculture policies and use these agreements to penetrate in the ever growing \$125bn Chinese food market;

IV. In the short and medium term, Pakistan ought to prioritize attracting FDI to lure nearterm inflows in order to strengthen the foreign reserves and ease pressure on BoP

\section{Long Term Policy Recommendations}

I. Increase research spending on, and financial support to industries that have high export potential, including rice sector and leather industry

II. Analysis of the case studies show that primary imports for China are raw materials (mainly iron-ore, coal, and copper), and Pakistan has a huge untapped potential in terms of raw materials and natural resources, this calls for further research in this area

III. Promote the Special Economic Zones under the CPEC and support the industries that have high export potential. For instance, the export potential of rice to China is estimated to be at $\$ 1143$ million and the current export is only limited to $\$ 193$ million.

IV. Diversifying the exports of the country and gradually moving towards high-value exports; switching from low-end agriculture products to manufacutred goods

$\mathrm{V}$. Include the list of products that Pakistan has comparative advantage over China in the new rounds of FTA, including rice, textiles, medical instruments, organic meat and leather

VI. Protect the domestic consumer goods industry which are vulnerable in mutual trade with China. 


\section{References}

Anzai, A., 2018, "Belt and Road provides landlocked Mongolia with chance to grow". Nikkei Asian Review.

Bank of Korea, 2012, Introduction of Korea-China Currency Swap-Financed Trade Settlement Facility. Ministry of Strategy and Finance, The Bank of Korea.

Bank of Mongolia, 2017, Mongolia's Foreign Trade Review.

CPEC - LTP, 2017, Long Term Plan for China-Pakistan Economic Corridor (2017-2030). Islamabad: Government of Pakistan; People's Republic of China.

Gabusi, Giuseppe., 2017 "Crossing the River by Feeling the Gold: The Asian Infrastructure Investment Bank and the Financial Support to the Belt and Road Initiative” 25, 23-24.

Huang, Y., 2016, "Understanding China's Belt and Road Initiative: Motivation, framework and assessment". China Economic Review , 40, 314-21.

Hussain, I., 2018, Business? Yes. As Usual? NO! Islamabad: The CPEC 2018 Summit Supplement. IMF, 2018, IMF Country Report Pakistan (Report No. 18/78). Washington.

IMF, 2017, IMF Country Report: Pakistan (Report No. 17/212). Washington: IMF.

IMF, 2017, Pakistan Selected Issues (Report No. 17/213). Washington: International Monetory Fund.

IMF, 2017, Thirtieth Meeting of the IMF Committee on Balance of Payments Statistics. Paris: International Monetory Fund.

Irshad, M. S., Xin, Q., \& Arshad, H., 2015, "One Belt and One Road: Dose China-Pakistan Economic Corridor benefit for Pakistan's Economy?". Journal of Economics and Sustainable Development , 6 (24).

Kamal, J., \& Malik, M. H., 2017, "Dynamics of Pakistan's Trade Balance with China". State Bank of Pakistan.

Kumar, A., 2006, "China-Pakistan Economic Relations". Institute of Peace and Conflict Studies (30).

Liang, Y., 2008, "Why Are China's Exports Special? The Role of FDI, Regional Trade, and Government Policies". The Chinese Economy , 41 (6), 99-118.

McDowell, Daniel., 2019, “The (ineffectivness) Financial Statecraft of China's Bilateral Swap Agreements"

Ministry of Finance, 2018, Pakistan Economic Survey 2016-17. Islamabad: Ministry of Finance.

Munro, A., \& Wooldridge, P., 2010, "Motivations for swap-covered foreign currency borrowing". BIS Papers.

Mustafa, S., \& Zafar, A., 2017, "China Pakistan Economic Corridor: Importance and challenges for Pakistan and China". International Journal of Social Science and Economic Research.

NTC, 2015, Reasons of Decline in Exports of Pakistan. National Tariff Commission. Government of Pakistan.

OEC, 2018, Retrieved 2018, from The observatory of the economic complexity: https://atlas.media.mit.edu/en/

OSCE, 2016, Latest from OSCE Special Monitoring Mission (SMM) to Ukraine. Kiev: Organization for Security and Co-operation in Europe.

Park, H.-S., 2016, "China's RMB Internationalization Strategy: Its Rationales, State of Play, Prospects and Implications". Harvard Kennedy.

PBC, 2018, 4th Review of the China Pakistan Free Trade Agreement (CPFTA) \& Recommendations for Phase II and Negotiations. Karachi: Pakistan Business Council.

PBS. 2018, Exports \& Imports of Pakistan. Retrieved from http://www.pbs.gov.pk/sites/default/files//tables/14.08\%20_o.pdf 
SBP, 2001, State Bank of Pakistan Annual Report FYo1.

Shah, A. R., 2018, "How Does China-Pakistan Economic Corridor Show theLimitations of China's‘One Belt One Road's Model". Asia and the Pacific Policy Studies , 5 (2), 378-385.

Small, A., 2017, "First Movement: Pakistan and the Belt and Road Initiative". Asia Policy.

Spivak, V., 2017, Why a Russia-China currency swap agreement turned out to be a damp squib. Retrieved 4 6, 2018, from Russia Beyond: https://www.rbth.com/business/2017/04/25/why-russia-china-currency-swap-agreementturned-damp-squib-750321

Stats NZ, 2018, "New Zealand's two-way trade with China more than triples over the decade". Retrieved from Stats NZ.

Swaine, M. D., 2015, "Chinese Views and Commentary on the "One Belt, One Road" Initiative". China Leadership Monitor (47).

Vangeli, A., 2017, "China's Engagement with the Sixteen Countries of Central, East and Southeast Europe under the Belt and Road Initiative". China and the world economy , 25 (5), 101-124.

Vorshilov, E., \& Ulzii-Ochir, N., 2016, "Analyzing the Impacts of Mongolia's Trade Costs". The Northeast Asian Economic Review.

Yelery, A., 2016, "China’s Bilateral Currency Swap Agreements: Recent Trends". China Report. Zhitao, L., Wenjie, Z., \& Cheung, Y.-W., 2016, "China's Bilateral Currency Swap Lines". EconStor. 


\section{APPENDICES}

Figure 7: Exports to China in 2006 (Pre FTA)

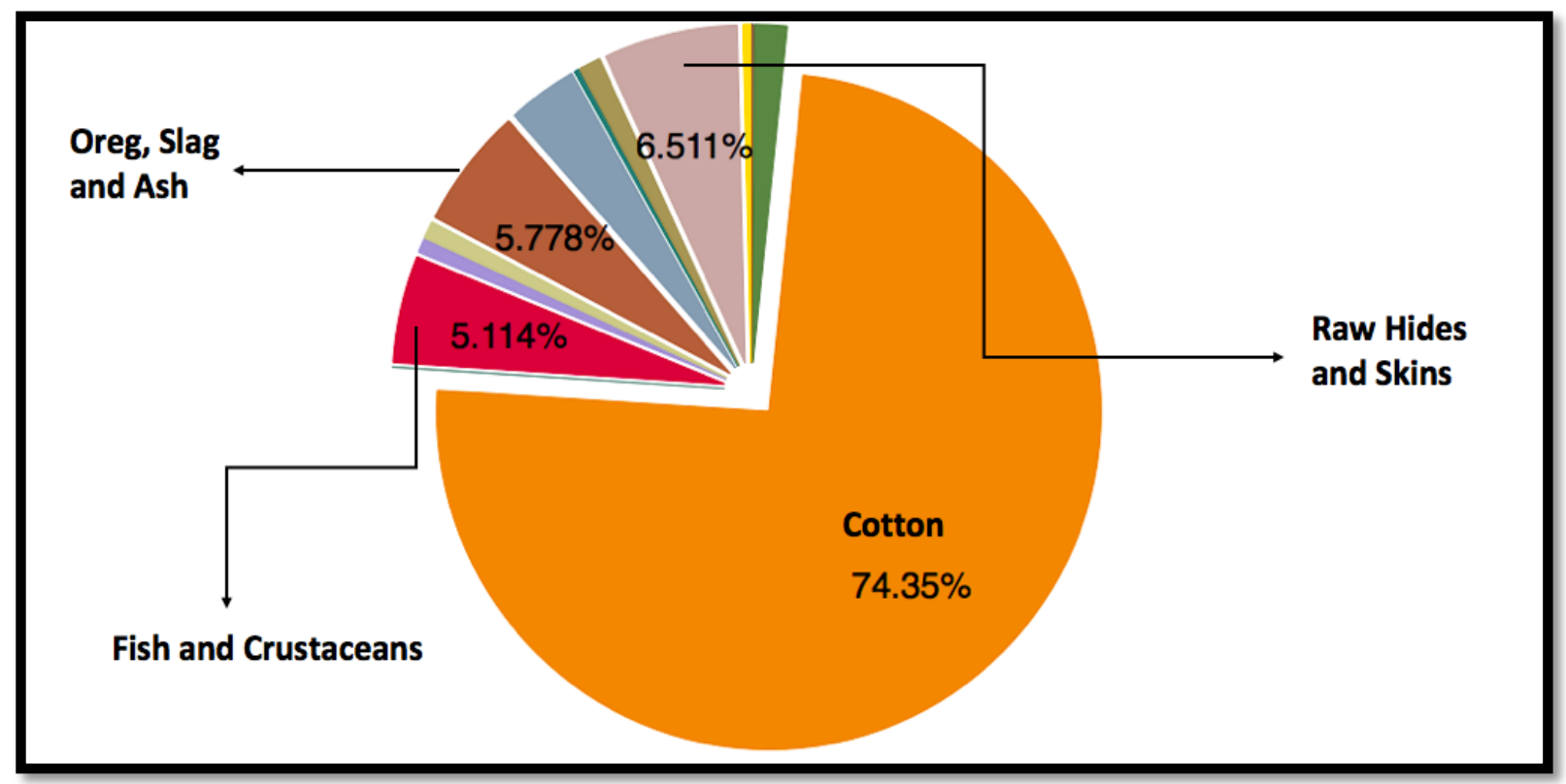

Source: Data collected from International Trade Center

Figure 8: Exports to China in 2018 (Post FTA)

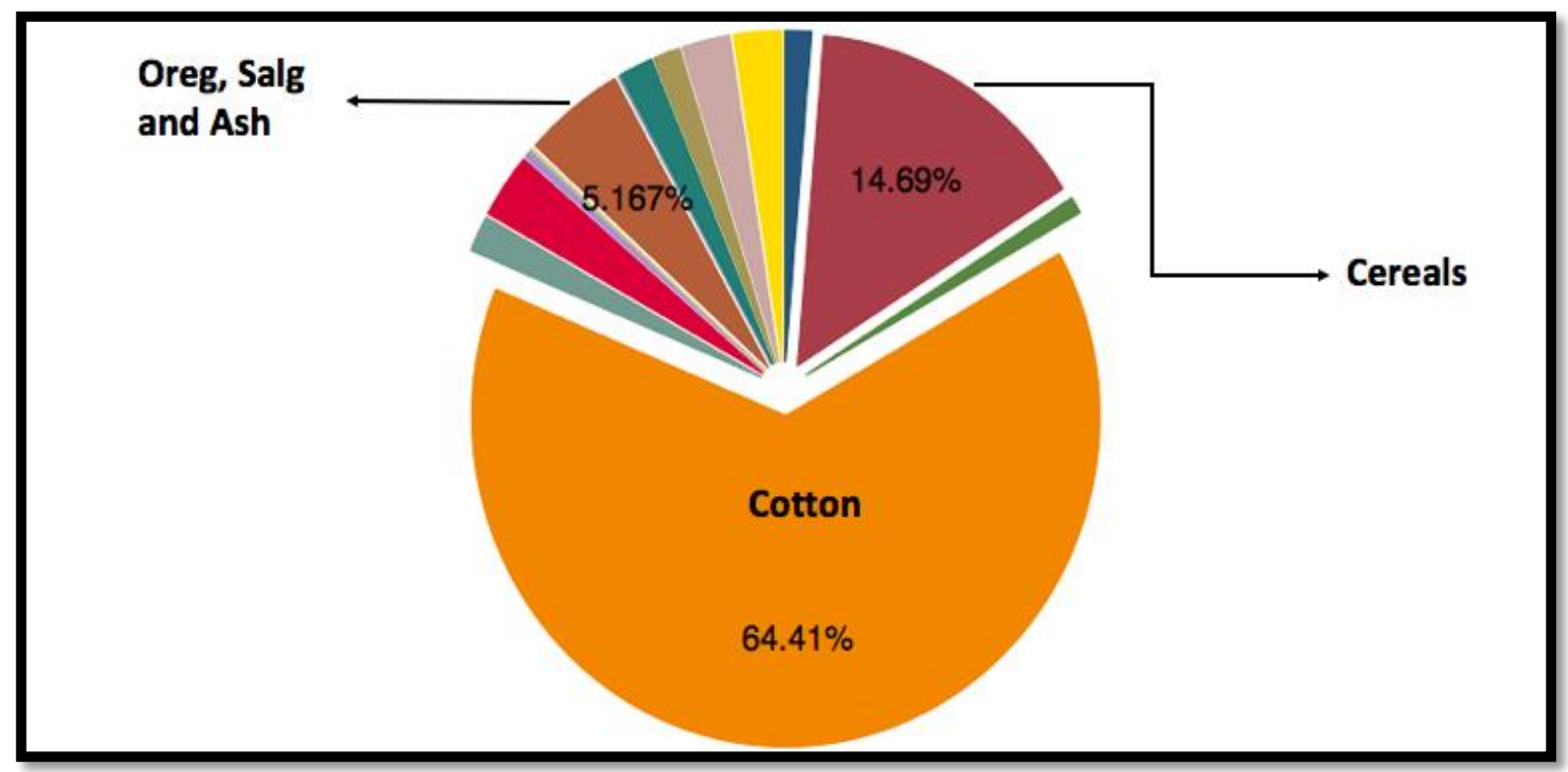


Review of Economics and Development Studies, Vol. 7 (4) 2021, 561 - 576

Figure 9: Imports from China in 2006 (Pre FTA)

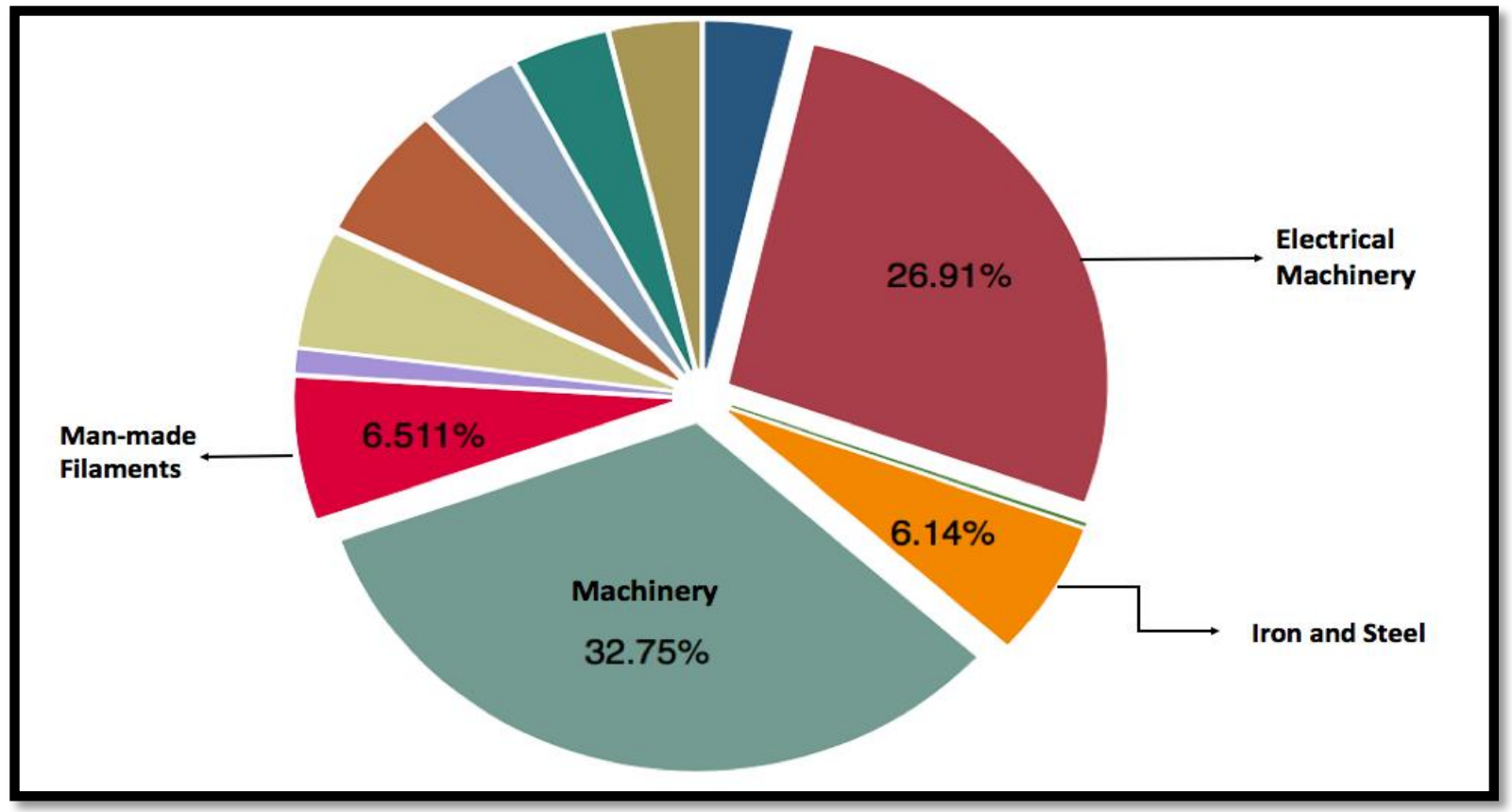

Figure 10: Imports from China in 2018 (Post FTA)

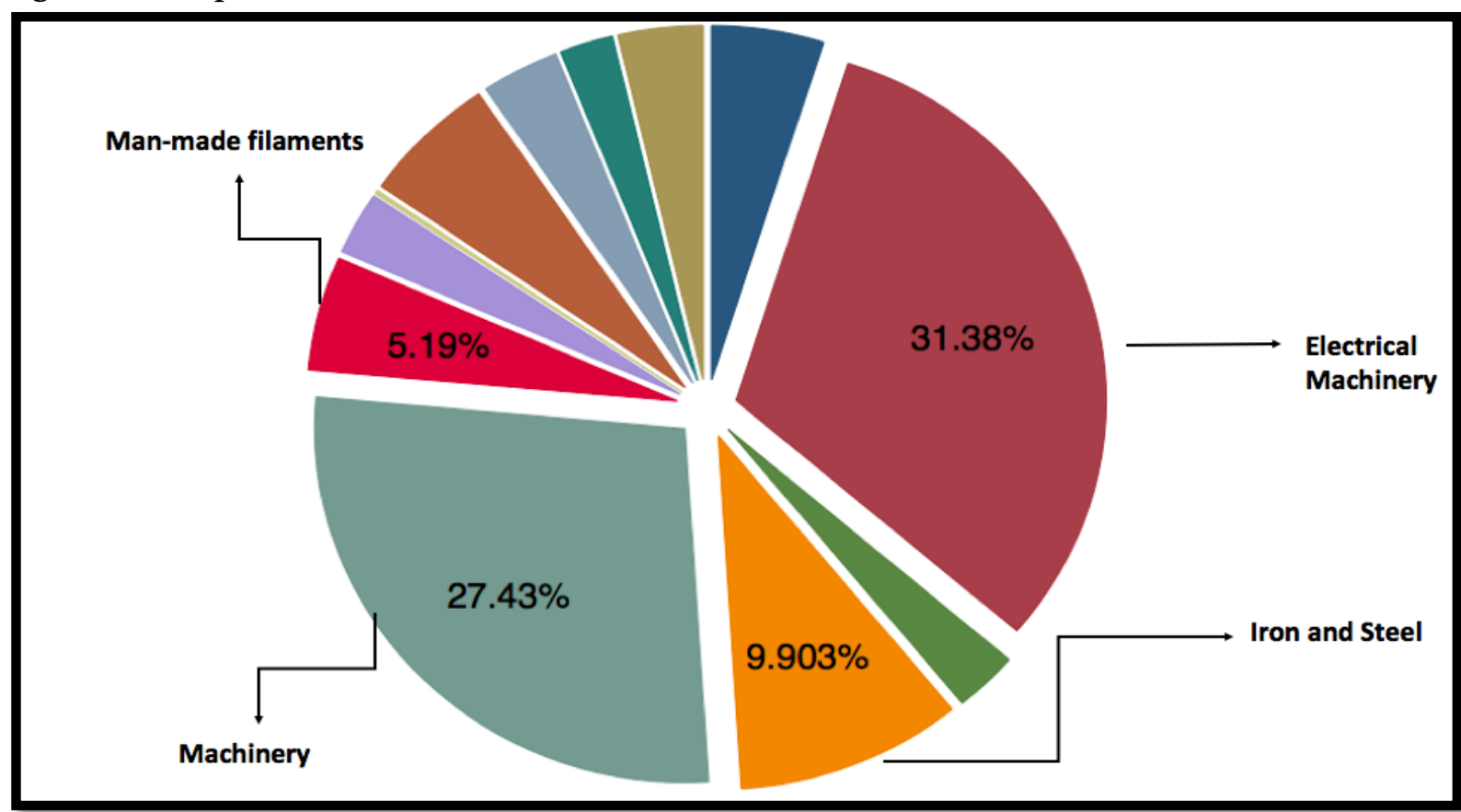


Review of Economics and Development Studies, Vol. 7 (4) 2021, 561 - 576

TABLE 4: Trends and Projections of Pakistan's Imports (USD Billions)

\begin{tabular}{|l|l|l|l|l|}
\hline \multicolumn{2}{|l|}{ 2012-2013 to 2017-18 } & Actual growth & \multicolumn{3}{l|}{ If Imports had grown at: } \\
\hline Year & & $5 \%$ & $\mathbf{1 0} \%$ & $\mathbf{1 5 \%}$ \\
\hline & 44.9 & - & - & - \\
\hline $2012 / 13$ & 45 & 47.1 & 49.4 & 51.6 \\
\hline $2013 / 14$ & 45.8 & 49.5 & 54.3 & 59.4 \\
\hline $2014 / 15$ & 44.7 & 52.0 & 59.8 & 68.3 \\
\hline $2015 / 16$ & 53 & 54.6 & 65.7 & 78.5 \\
\hline $2016 / 17$ & 60.8 & 57.3 & 72.3 & 90.3 \\
\hline $2017 / 18$ & & & & \\
\hline
\end{tabular}

TABLE 5: Projections of Pakistan's Imports (USD Billions)

\begin{tabular}{|l|l|l|l|}
\hline 2018-19 to 2023-24 & \multicolumn{4}{l|}{ If Imports grow at: } \\
\hline Year & $\mathbf{5 \%}$ & $\mathbf{1 0} \%$ & $\mathbf{1 5 \%}$ \\
\hline $2018 / 19$ & 63.8 & 66.9 & 69.9 \\
\hline $2019 / 20$ & 67.0 & 73.6 & 80.4 \\
\hline $2020 / 21$ & 70.4 & 80.9 & 92.5 \\
\hline $2021 / 22$ & 73.9 & 89.0 & 106.3 \\
\hline $2022 / 23$ & 77.6 & 97.9 & 122.3 \\
\hline $2023 / 24$ & 81.5 & 107.7 & 140.6 \\
\hline
\end{tabular}

Source: Data collected from Pakistan Bureau of Statistics 